\title{
メタンを燃料に用いた場合の管状火炎バーナの燃焼特性*
}

\author{
萩原良一*1, 岡 本昌也*1, 石塚 悟*2 \\ 小林秀峰*3, 中村 章*4, 鈴木 実*5
}

\section{Combustion Characteristics of a Tubular Flame Burner for Methane}

\author{
Ryoichi HAGIWARA, Masaya OKAMOTO, Satoru ISHIZUKA*6, \\ Hideo KOBAYASHI, Akira NAKAMURA and Minoru SUZUKI
}

\author{
${ }^{* 6}$ Hiroshima University, Dept. of Mechanical Engineering, \\ 1-4-1 Kagamiyama, Higashi-Hiroshima, Hiroshima, 739-8527 Japan
}

\begin{abstract}
Combustion characteristics of a tubular flame burner, which has been developed previously for propane, have been investigated with using methane as a fuel. The results show that the combustion characteristics for methane are almost the same as those for propane. Namely, (1) the equivalence ratio at the lean limit is about $0.5,(2)$ the wall temperature at the injection section is kept low, and (3) the burned gas temperature is uniform in the axial direction. However, (4) a tubular flame with a large laminar flame area of $0.24 \mathrm{~m}^{2}$ is obtained with lean mixtures, (5) the stable flame region in the fuel-rich side is very narrow, $(5)$ the equivalence ratios at which the flame diameter, the flame length, and the flame temperature take their maxima or minima are shifted to 0.9 , and ( 6 ) the volumetric burning rate becomes $50 \%$ less or more than the total mixture volume flow rate for the near lean- and rich-limit mixtures, although they agree well for the stoichiometric mixture.
\end{abstract}

Key Words: Tubular Flame, Burner, Methane, Combustion, Laminar Flame, Preferential Diffusion

\section{1. まえがき}

管状火炎は，円筒座標系の火炎素として，もっぱら， 基礎然焼学の立場から研究されてきたが(1) (4), 温度分 布の対称性から断熱性が高く熱的に安定なうえに, 空 気力学的にも流れの回転運動に対して安定であり, 実 用燃焼器に供する火炎として優れた特性をもってい る. 特に，希薄予混合燃焼が極めて容易に実現される 任か，過濃混合気の場合に排出されるすすも伸長率を 増やすことで抑制できるので，環境負荷低隇をはかる うえで, 大きな潜在性を秘めている.このような背景 のもとで，最近，実用に供するような大きな発熱量を もつ管状火炎バーナがプロパンを燃料として開発され た(5). 今回は，管状火炎バーナの有用性を確かめるべ く，天然ガスの主成分であるメタンを燃料とした場合 の燃焼特性を調べ，その特徵や実用上での問題点など を抽出することにした。

* 原稿受付 2000 年 4 月 19 日.

*1 広島大学大学院 (画 739-8527 東広島方鏡山 1-4-1).

*2 正員, 広島大学工学部.

*3 日本鋼管(株)総合エンジニアリング事業部 (画230-8611 横 浜市鶴見区末広町 2-1)。

*4 日本鋼管(株)エンジニアリング研究所(画 210-0855 川崎市 川崎区南渡田町 1-1).

*5 正員, 日本鋼管 (株)エンジニアリング研究所.

E-mail : ishizuka@mec.hiroshima-u.ac.jp

\section{2. 実 験 装 置}

管状火炎バーナには，前回(5) と同じものを用いた [文献 ( 5 ), 図 2,3 参照]。バーナは混合気吹出し部と 燃焼管部からなり，バーナ径は 4 in である。混合気吹 出し部には, $3.7 \mathrm{~mm} \times 95.4 \mathrm{~mm}$ の矩形断面のスりッ 卜が対称位置に 2 個, 接線方向に取付けられており, 吹出し部長さは $160 \mathrm{~mm}$, バーナの一端には観察用に 石英ガラス空が設けられている。このガラス空とは反 対側に, 内径 $100 \mathrm{~mm}$, 長さ $1000 \mathrm{~mm}$ のパイレック ス管を取付けて燃焼室とし，ビデオカメラを用いて火 炎の観察を行った。温度測定時は, 全長 $500 \mathrm{~mm}$ の測 定孔付きの管をパイレックス管の代わりに装着し, 素 線径 $500 \mu \mathrm{m}$ のR 形熱電対 $(\mathrm{Pt} / \mathrm{Pt}-13 \% \mathrm{Rh})$ を挿入し 測定を行った。

空気はターボブロワ(武藤電気：MI- $12 \mathrm{~N} / 6$, 定格 風量 $7.0 \mathrm{~m}^{3} / \mathrm{min}$, モ一夕出力 $2.2 \mathrm{~kW}$, 最大昇王 $1300 \mathrm{mmAq})$ から, メタン $\left(\mathrm{CH}_{4}: 99.52 \%, \mathrm{CO}_{2}:\right.$ $\left.0.42 \%, \mathrm{~N}_{2}: 0.05 \% \mathrm{~mol}\right)$ は高圧ボンべから供給し, そ れぞれ浮き子式面積流量計で流量を測定した後混合 し, バーナに供給した。流量計の検定には, 小流量の 場合は湿式流量計 $\left(\sim 6 \mathrm{Nm}^{3} / \mathrm{h}\right)$ を用い, 大流量の場合 は, 矩形断面 $(30 \mathrm{~mm} \times 120 \mathrm{~mm})$ の吹出し出口をもつ 
二次元風洞，あるいは，出口直径 $18 \mathrm{~mm}$ の八分円ノ ズルを用い，出口での流速分布をピトー管で測定して 行った. 今回は, 流量計の容量の関係で, 空気流量と しては 20〜 $140 \mathrm{Nm}^{3} / \mathrm{h}$, メタンの流量としては 20 $\mathrm{Nm}^{3} / \mathrm{h}$ 以下の範囲で実験を行った。

\section{3. 実 験 結 果}

$3 \cdot 1$ 火炎外観 メタンを燃料として用いた場合 も, プロパンと同様, 電気火花で着火すると極めて容 易に管状火炎が形成され，その外観もプロパンの場合 とほとんど同様であった. 参考に, 先のプロパン火炎 の外観 [文献 $(5)$, 図 4 参照] と同じ空気流量 80 $\mathrm{Nm}^{3} / \mathrm{h}$ 一定のもとでの当量比による火炎形状の変化 を図 1 に示す。左側はバーナ端の石英空から撮影した 結果, 右側はパイレックス管部の撮影結果で, 縮尺は 異なる。

当量比 $\Phi=1$ [図 1(a)] では, 円形断面の火炎が 吹出し部全長 $(160 \mathrm{~mm})$ にわたって一様に管壁にへば りつくようにして形成され，その青炎の端は吹出し部 内にある(パイレックス管部の発光は, 燃焼ガスのふ く射による). 燃料流量を減らしていくと, 火炎直径 はやや減少し, 同時に, 青炎の端は混合気吹出し部よ り出てパイレックス管部まで伸び [図 1(b)],さらに 燃料の流量を減らすと火炎は吹出し部から吹き飛び, パイレックス管内に先端部が抜けた状態の逆円錐状の 青炎が形成される [図 1(c)].さらに燃料の流量を

(a)
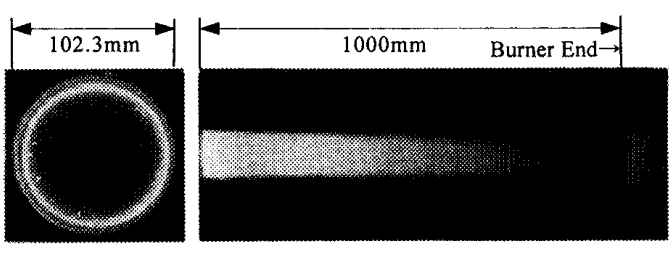

(b)
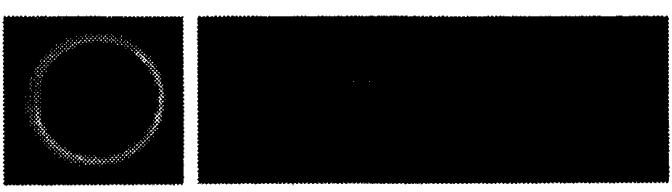

(c)
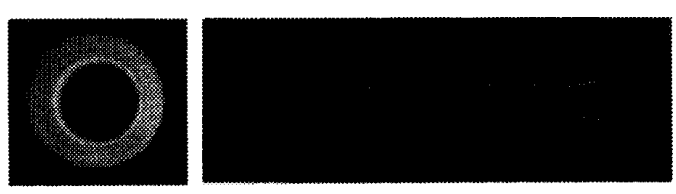

(d)
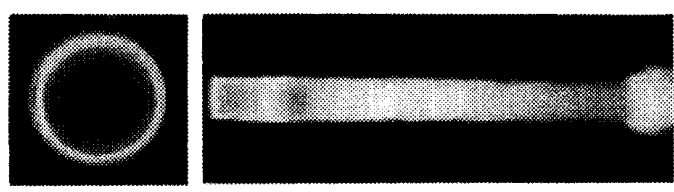

Fig. 1 Appearance of methane flame $\left[Q_{a i r}=80 \mathrm{Nm}^{3} / \mathrm{h}\right.$, (a) $\Phi=1.0$, (b ) $\Phi=0.6$, (c) $\Phi=0.57$, (d) $\Phi$ $=1.2]$
減らすと, 火炎はパイレックス管の外に押し出される ようにして吹き飛ぶ.

一方， $\Phi=1.0$ の状態から燃料の流量を增やすと, 希薄混合気の場合と同様, 火炎直径は徐々に減少し, 同時に火炎は伸びてパイレックス管部に入り [図 $1(\mathrm{~d})]$, さらに燃料の流量を増やすと, 火炎は吹き飛 んでパイレックス管出口に拡散火炎を伴った過濃火炎 が形成された。

プロパンでは, 過濃可燃限界 (当量比 $2.51^{(6)(7)}$ ) 付近 になると輝炎の発光が強くなり青炎の確認が難しい が, 過濃可燃限界を超えても火炎が存在し, これは, 燃焼ガスの再循環領域の形成が一因と考えられるが [文献 (4), 図 38 参照], メタンでは過濃可燃限界にお ける当量比が $1.69^{(6)(7)}$ と小さいせいか, 燃料を過㮃に していくと火炎が吹き飛び，プロパンと著しい違いを 示した。

一方, 当量比を一定に保ちつつ混合気流量を増加さ せると, 火炎長(バーナ端から青炎の端までの長さで 定義) は増加し, 火炎直径は徐々に減少した。参考に, $\Phi=0.6$ の場合の外観を図 2 に示す. 流量の増加に伴 いほほ直線的に火炎長が長くなることがわかる。

$3 \cdot 2$ 消炎限界 図 3 に, 火炎形成限界での当量 比 $\Phi$ を総流量 $Q_{\text {total }}$ (空気流量 $Q_{\mathrm{alr}}$ と燃料の流量 $Q_{\mathrm{fuel}}$ の和)に対して求めた結果をプロパンの結果とともに 示す。参考に, 横軸には, 総流量をスリット断面積で 除して求めた接線方向吹出し平均速度 $V_{t}$, 総流量を 管断面積で除して求めた軸方向平均速度 $V_{a}$, および, 流れ場の伸長率の目安である速度こう配 $\alpha$ (総流量を 吹出し部円筒表面積で割って求めた半径方向平均吹出 し速度 $V_{n}$ を管半径で除したもの)も示されている.

(a)
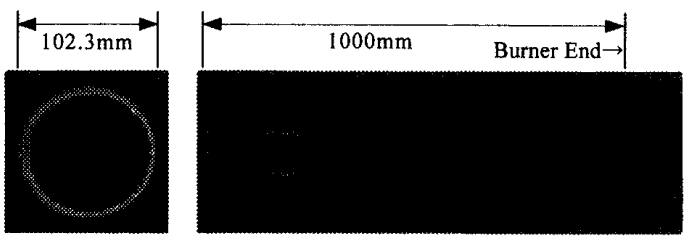

(b)
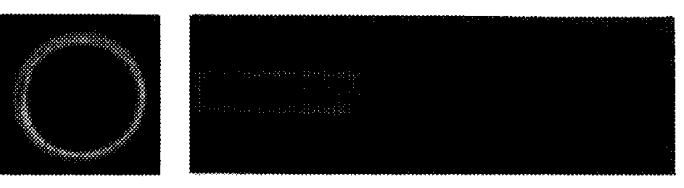

(c)
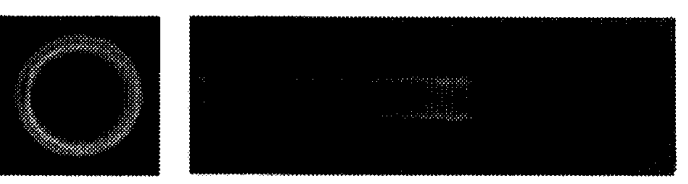

Fig. 2 Variations of the flame configuration of $\Phi=0.6$ with the air flow rate $\left[(\right.$ a $) Q_{a i r}=60 \mathrm{Nm}^{3} / \mathrm{h}$, (b) $Q_{a i r}=100 \mathrm{Nm}^{3} / \mathrm{h}$, (c) $Q_{\text {air }}=140 \mathrm{Nm}^{3} / \mathrm{h}$ ] 


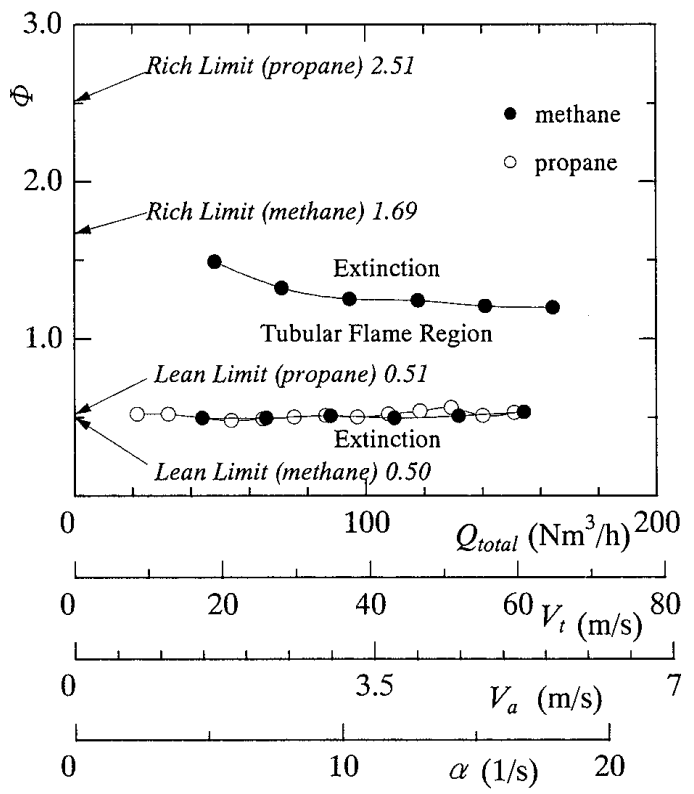

Fig. 3 Extinction limit

希薄限界における当量比は, プロパンの場合と同様, 総流量の広い範囲でほほ一定值約 0.5 をとり, 希薄可 燃限界 (メタン: $0.50^{(6)(7)}$, プロパン: $\left.0.51^{(6)(7)}\right)$ 近くま で火炎が存在できることがわかる。しかし，過濃限界 における当量比は, 総流量が $45 \mathrm{Nm}^{3} / \mathrm{h}\left(\alpha \cong 5 \mathrm{~s}^{-1}\right)$ と

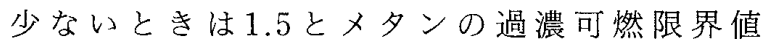
$\left(1.69^{(6)(7)}\right)$ に近いが, 総流量を増やすと, 単調に隇少 し, 総流量約 $160 \mathrm{Nm}^{3} / \mathrm{h}\left(\alpha \cong 18 \mathrm{~s}^{-1}\right)$ のときでは 1.25 と理論混合気に近くなっている.つまり，メタンの場 合, プロパンに比べて燃料過剒側における火炎の安定 範囲が狭い. したがって, 管状火炎バーナを当量比 1.1 (空気過剩率 0.9 ) 付近の還元雾囲気状態において 長時間大流量で運転するときには, 燃料や空気の流量 変動による消炎に十分注意与る必要がある。

$3 \cdot 3$ 火炎直径および火炎長さ次に, 混合気吹 出し部における火炎直径および火炎長さの当量比によ る変化を調べた。図 4,5 に空気流量 $80 \mathrm{Nm}^{3} / \mathrm{h}$ およ び $140 \mathrm{Nm}^{3} / \mathrm{h}$ のをの結果をプロパンの結果ととも に示す。

基礎研究用バーナの結果によれば，ルイス数の 1 よ り小さい希薄メタン，あるいは，過濃プロパン混合気 では火炎直径が小さくなって消炎するのに対し，ルイ ス数の1より大きい過濃メタン, あるいは, 希薄プロ パン混合気では火炎直径はあまり小さくならずに消炎 することが知られている(1)(3)(4).

しかし，今回のバーナの希薄側を見ると，消炎限界 における火炎直径のメタンとプロパンによる違いは見 られなかった。しかし，過濃側では，プロパンでは火 炎直径が当量比の増加とともに小さくなって消炎する

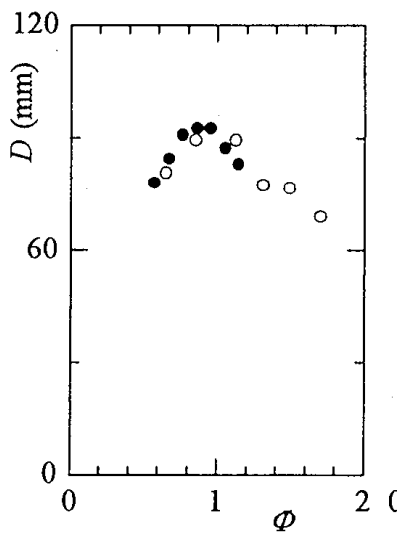

(a)

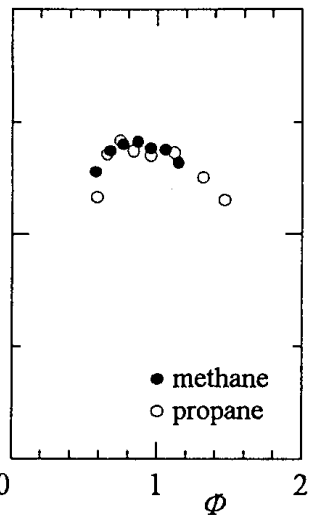

(b)
Fig. 4 Variations of the flame diameter $D$ with the equivalence ratio $\Phi\left[\right.$ ( a ) $Q_{a i r}=80 \mathrm{Nm}^{3} / \mathrm{h}$, (b) $\left.Q_{\text {air }}=140 \mathrm{Nm}^{3} / \mathrm{h}\right]$

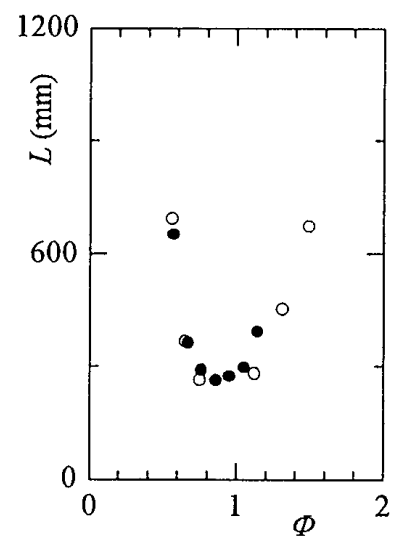

(a)

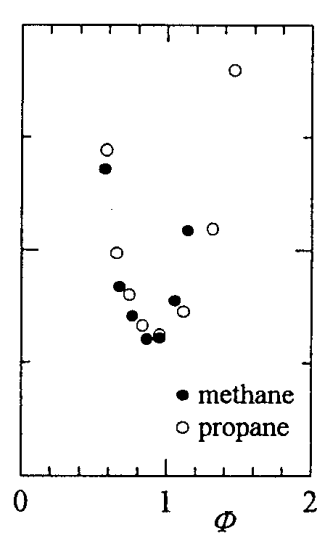

(b)
Fig. 5 Variations of the flame length $L$ with the equivalence ratio $\Phi\left[\right.$ ( a ) $Q_{a i r}=80 \mathrm{Nm}^{3} / \mathrm{h}$, (b) Qair $=$ $\left.140 \mathrm{Nm}^{3} / \mathrm{h}\right]$

のに対し，メタンでは直径が小さくならずに消炎し， 基礎研究用のバーナで観察されたルイス数効果と定性 的に一致する結果が得られている。しかしながら，現 在得られている管状火炎は，中心軸上からかなり離れ た位置に形成されており，基礎研究用のバーナで得ら れる火炎とは流れ場がかなり違っている。したがっ て, プロパンの過濃火炎の直径がメタンの過濃火炎に 比べ小さくなるのは, ルイス数効果で考えるより, 単 純に, プロパンの過濃側は可燃範囲が広く, 燃焼速度 の小さな混合気に対してまで火炎が形成可能となり， 結果的に, 火炎と直角方向の半径方向速度がより小さ な中心部位置まで火炎が形成され，一方，メタンでは 過濃側の可燃範囲が狭く, 燃焼速度の大きな混合気で も吹き消えるため, 小さな直径の火炎が得られないも 


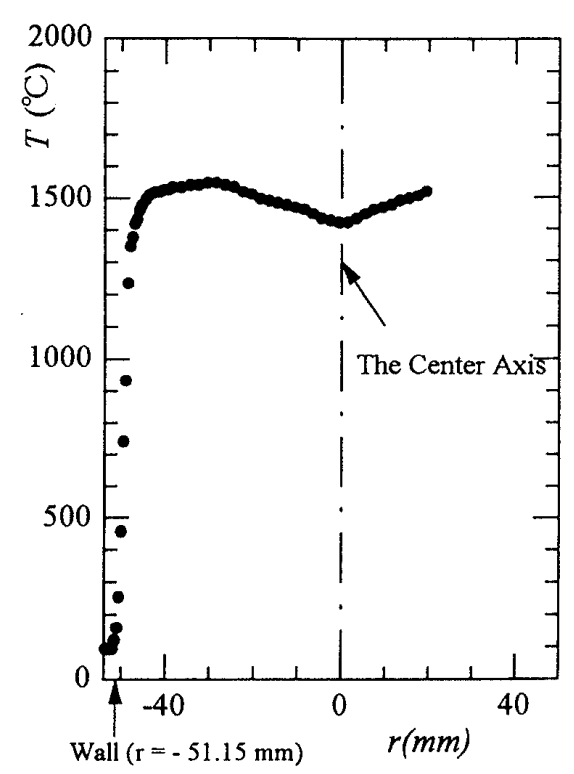

Fig. 6 Radial temperature distribution $\left[Q_{a i r}=80 \mathrm{Nm}^{3} /\right.$ h, methane: $\Phi=1.06$, propane: $\Phi=0.94$ )

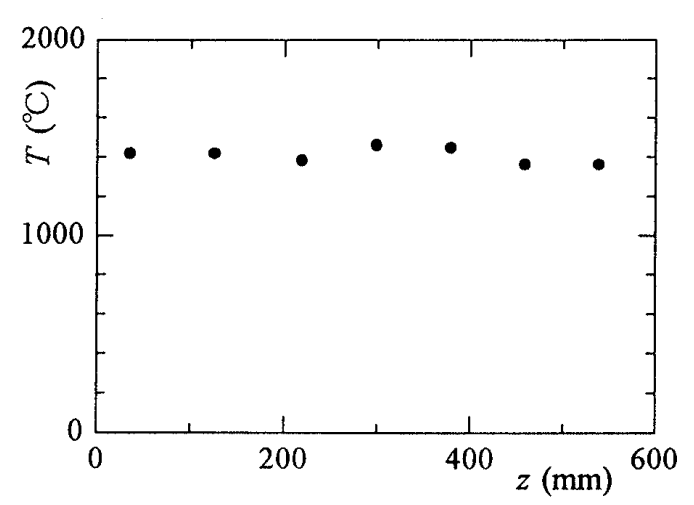

Fig. 7 Axial temperature distribution $\left(Q_{a i r}=80 \mathrm{Nm}^{3} / \mathrm{h}\right.$, methane: $\Phi=1.04$, propane : $\Phi=0.96$ )

のと考えられる。

なお，火炎直径扔よび火炎長さは，図 4, 5 に示され ているように, 当量比 1.0 付近でそれぞれ最大, 最小 值をとるが，そのピーク位置を詳しくみると，メタン の場合はプロパンに比べより希薄側にずれ, 当量比 0.9 付近となっている.

$3 \cdot 4$ 火炎温度分布 図 6,7 に, 半径方向および 中心軸上の軸方向温度分布をそれぞれ示す。半径方向 温度分布は, プロパン同様 $\mathrm{M}$ 形を示し, 火炎を隔てて 外側は常温の未燃ガス, 内側は高温の燃焼ガスとなっ ている.したがって，メタンを燃料とした場合も自己 冷却作用によりバーナ吹出し部壁面が常温に保たれ, バーナが長時間運転可能なことがわかる，一方，軸方 向温度分布もプロパン同様，バーナ全長にわたりほと んど一定であり，均一な燃焼ガスの領域が実現されて いることがわかる。

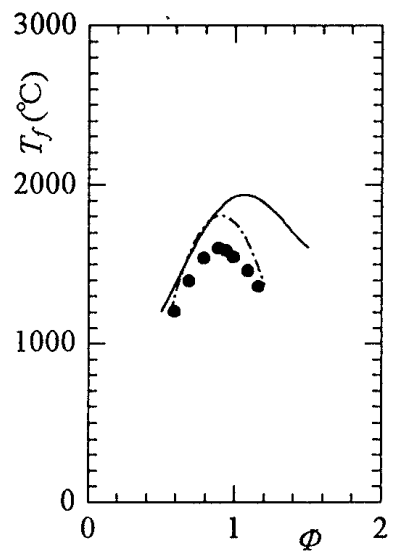

(a) Methane

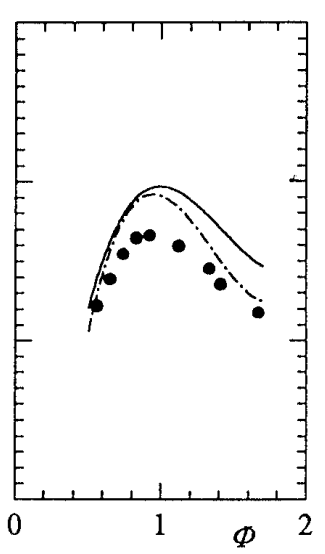

(b) Propane
Fig. 8 Variations of the flame temperature with the equivalence ratio $\left(Q_{a i r}=80 \mathrm{Nm}^{3} / \mathrm{h}\right)$

3.5 火炎温度図 8 にバーナ端から $80 \mathrm{~mm} の$ 断面位置に扔ける火炎温度 $T_{f}$ (反応带に扔ける最高 温度)の当量比による変化を示す. 図 8 中実線は, 平 衡計算 ${ }^{(8)}$ で求めた値,一点鎖線は R 形熱電対の測定

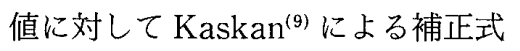

$$
\Delta T=\frac{1.25 \varepsilon \sigma T_{w}^{4} d^{0.75}}{\lambda}\left(\frac{\eta}{\rho v}\right)^{0.25}
$$

によりふく射補正を施したものである。ただしここ で，ยは放射率で被覆のない手熱電対では $0.16, \sigma$ はステファン・ボルツマン定数で $5.670 \times 10^{-8} \mathrm{~W} /$ $\left(\mathrm{m}^{2} \cdot \mathrm{K}^{4}\right), T_{w}$ は熱電対の温度, $d$ は熱電対の素線径, $\lambda, \eta, \rho, v$ はそれぞれ燃焼ガスの熱伝導率, 粘性係数, 密度, 速度で, 熱伝導率や粘性係数などの物性值は, 平衡計算で求められた組成の燃焼ガスに対して気体運 動論で与えられる推定式(10)を適用して求め, また, 燃 焼ガスの速度としては，火炎がバーナ壁近くに形成さ れるので, 接線方向速度にほぼ等しいものと考え(11), 接線方向吹出し平均速度 $V_{t}$ を用いた。

よく知られているように, 平衡計算結果 (実線) は, $\Phi=1.0$ よりやや燃料過濃側でメタンもプロパンも最 高となっているが, 測定結果(○印)は, メタン, プロ パンとも燃料希薄側の $\Phi=0.9$ 付近で最高温度とな り，そこから燃料希薄にしても燃料過㮃にしても温度 は低下し，特に，メタンの過濃側での温度の低下が著 しい.ふくく射補正を施した值 (一点鎖線)を見ると，メ タン, プロパンとも当量比 0.9 以下の燃料希薄側では ほとんど平衡計算結果と一致するが，理論混合気およ び燃料過濃側では, 補正值は平衡計算値に比べ低くな り，その差はプロパンではせいぜい $200^{\circ} \mathrm{C}$ 程度である のに対し，メタンでは当量比の増加とともに補正值は 著しく低下し, 平衡計算值よりも $500^{\circ} \mathrm{C}$ 近く下回るこ 
とがわかる，この火炎温度の低下は，メタンの過濃側 で火炎安定範囲が著しく狭くなる事実と深く関係して いるものと考えられる。

\section{4. 考察}

管状火炎バーナの特徵は, 実用バーナの多くが高効 率・高負荷形の乱流燃焼を用いているのに対し，西く まで層流火炎を用い，この層流火炎を大規模に作って 用いる点である。そのため，燃焼は乱流という不確定 要素を含まない管理された状態で行われるほか,いわ 汹るスケールエフェクト (寸法効果)の問題がなく，事 実, 先のプロパンを燃料とした場合の実験で確かめら れたように，体積燃焼速度は理論值である総流量にほ ほ等しく、これから逆算して, 発熱量に見合ったバー ナ長が予測可能となる( ${ }^{(5)}$.

そこで，今回は，メタンについてもこれが成り立つ かどうかを検証することにした：はじめに，火炎直径 および火炎長さから得られた火炎面積の当量比による 変化を, 空気流量 $80 \mathrm{Nm}^{3} / \mathrm{h}$ と $140 \mathrm{Nm}^{3} / \mathrm{h}$ の場合に ついてプロパンの結果とともに図 9 に示す．火炎面積 は, プロパンでは当量比 1.0 付近を最小に, 燃料希薄 側, 燃料過剩側で増加しているが，火炎直径・長さの 結果から予想されるようにメタンではその最小値はプ ロパンに比べより希薄側にずれ，当量比 0.9 付近まで ずれている．また，プロパンの場合，過濃側 $(\Phi=1.6)$ で非常に引きのばされた火炎が形成されるため面積の 大きな火炎が得られるのに対し，メタンでは，過濃側 では容易に火炎が吹き飛ぶため, むしろ希薄側で長い 火炎，したがって大きな面積の火炎 (約 $0.24 \mathrm{~m}^{2}$ ) が得 られている.

この面積 $A$ に燃焼速度 $S_{u}$ をかけ求めた体積燃

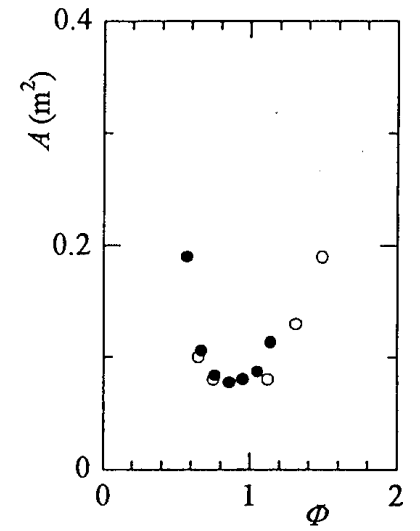

(a)

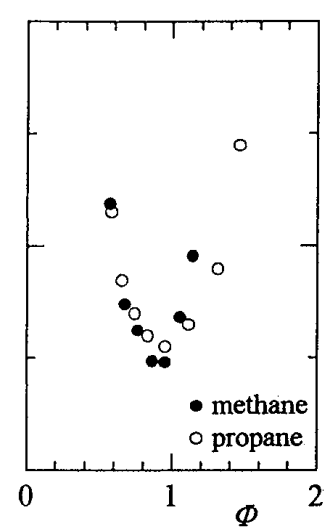

(b)
Fig. 9 Variations of the flame area $A$ with the eqivalence ratio $\Phi\left[\right.$ ( a ) $Q_{a i r}=80 \mathrm{Nm}^{3} / \mathrm{h}$, (b) $Q_{\text {air }}=140$ $\left.\mathrm{Nm}^{3} / \mathrm{h}\right]$
焼速度 $Q_{\text {burning }}\left(=A \cdot S_{u}=Q_{\text {total }}\right)$ の当量比による変化 を図 10 亿示す。ここで燃焼速度としては, 対向流火 炎法 ${ }^{(12)}$ による結果を用いた。破線は理論值である総 流量 $Q_{\text {total }}$ で, 非常にわずかであるが当量比の増加と ともに増加する。当量比 1 付近ではメタン, プロパン いずれも体積燃焼速度と総流量はほぼ等しく理論どお りとなっているが, 希薄側・過濃側にすすむにつれ理 論值からのずれが大きくなり，また，プロパンに比べ メタンのほうのずれが大きい.

図 11 は，段階的に空気流量を変えて，同じ実験を繰 返し，代表的な当量比における体積燃焼速度 $Q_{\text {burnnng }}$ と総流量 $Q_{\text {total }}$ との関係を求めた結果である。体積燃 焼速度は混合気流量と等しくなるべきであるので, 両 者の等しくなる状態を $Y=X$ で図 11 中に示した. プロパンでは，理論混合気 $(\Phi=1.0)$ の場合はほとん

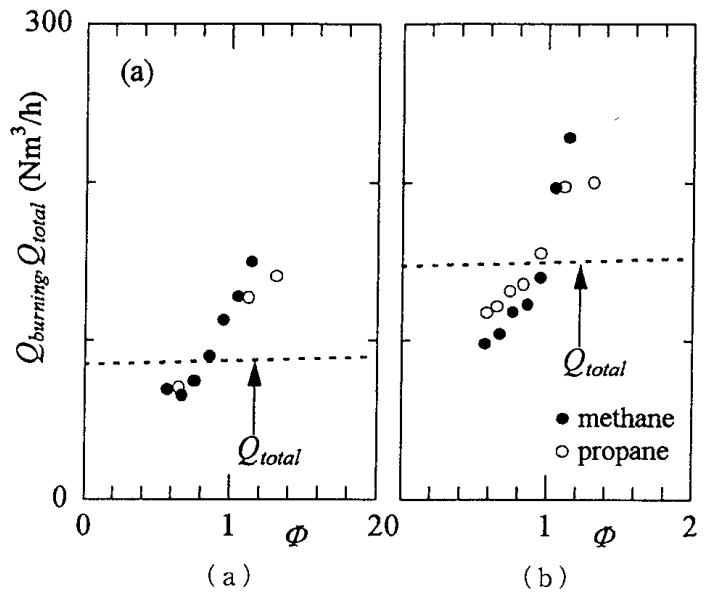

Fig. 10 Variations of the volume burning rate $Q_{\text {burning }}$ and the total mixture flow rate $Q_{\text {total }}$ with the equivalence ratio $\Phi\left[\right.$ ( a ) $Q_{a i r}=80 \mathrm{Nm}^{3} / \mathrm{h}$, (b) $\left.Q_{\text {air }}=140 \mathrm{Nm}^{3} / \mathrm{h}\right]$

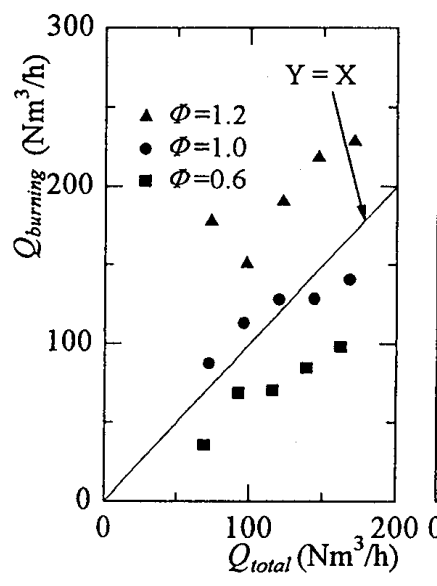

(a) Methane

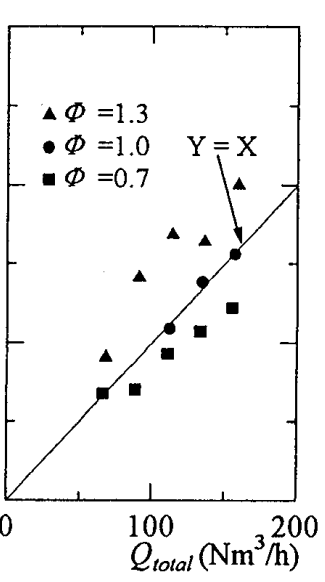

(b) Propane
Fig. 11 Variation of the volume burning rate Qburning with the total mixture flow rate $Q_{\text {total }}[(\mathrm{a})$ methane, ( $b$ ) propane] 
どこの理論直線上にのり，過濃混合気では若干高め, 希薄混合気では低めとなるが, 3 割程度以内で体積燃 焼速度は混合気流量に等しくなっている。したがっ て, 逆算により火炎長, ひいてはバーナ長さが推測で きることがわかる(5).

しかし,メタンの場合, 理論混合気では比較的体積 燃燒速度と混合気流量との一致はよいが, 希薄混合気 や過濃混合気ではプロパンに比べ両者の一致が悪く, 特に過濃側で当量比が 1.0 から 1.2 となっただけで理 論值に比べ $50 \%$ 多くなっている。これから，メタン を燃料として用いる場合，理論混合気付近であれば問 題はないが, 希薄可燃限界や過濃可燃限界付近の混合 気を燃焼させる場合, 簡単な体積燃焼速度の関係から 火炎長を推測してバーナ長を決定すると $50 \%$ 程度食 い違う恐れがあることがわかる。

ところで, このようにメタンの希薄および過濃混合 気で体積燃焼速度が総流量から大きくずれてしまう原 因としては, プロパンに比べてメタンの場合, 図 4, 5, および図 8 の結果が示すように, 火炎直径や火炎長さ， 火炎温度のピーク位置がより希薄側に移動し, 燃焼速 度が最大となる当量比 (メタンの場合 $1.05^{(10)}$ ) とかな りずれたことが考えられる.

この場合, 例えば過濃混合気の場合, 実際の管状火 炎の火炎温度 $T_{f}^{*}$ は, 本来の断熱火炎温度 $T_{f}^{0}$ に比べ 低くなるので, 反応速度が低下して燃焼速度 $S_{u}^{*} か ゙$ 本 来の $S_{u}^{0}$ よ遅くなる。すると, 同じ流量の未燃混合 気に対し火炎面積 $A^{*}$ は, 本来の面積 $A^{0}$ (燃焼速度が Sルのときにできるべき火炎面積)に比べ大きくなる ことになるが, 体積燃焼速度の算出にあたっては, こ の大きくなった火炎面積 $A^{*}$ に対して，これに対応す る燃焼速度 $S_{u}^{*}$ をかるべきところ, 元の断熱火炎温 度 $T_{f}^{0}$ の火炎の燃焼速度 $S_{u}^{0}\left(>S_{u}^{*}\right)$ を加けて求めるの で, 結果として計算される体積燃焼速度は, その理論 値である混合気流量より大きくなったと考えられる。

ところで,メタンの場合, プロパンに比べてなぜピ 一ク位置がより希薄側にずれるかであるが, 単純には, いわゆる選択拡散が挙げられる。よく知られているよ うに, 伸長流中においては, 流管を通して物質移動が あるため，火炎が形成できる最大の伸長率を与える混 合気は,メタン・空気混合気では理論混合気より希薄 側に,プロパン・空気混合気では過濃側にずれ る(4)(13).また，低伸長流中で測定される希釈限界でも， 最大の希积濃度を与える混合気は, メタンでは希釈側 にずれて当量比 0.87 で,プロパンではかなり過濃側 にずれて当量比 1.75 となる(14). したがって,メタン の火炎温度が希薄側にずれる要因としては，伸長流場
における選択搪散が考える。しかし，図８亿示した結 果は伸長率 $\alpha$ が $9 \mathrm{~s}^{-1}$ とかなり小さい場合の結果であ るうえに，同様に選択拡散が起こり得るプロパン混合 気で，なぜピーク位置が逆に過濃側にずれないかとい う疑問が残る。

そこで，もう一つの可能性として，圧力拡散が考え られる。すなおち，管状火炎は，回転流中に形成され るので, 遠心力によりバーナ中心部では圧力が低い状 態となって扔り，压力こう配が存在する，すると，分 子量のより小さいメタンが, 分子量のより大きい酸素 に比べて相対的に多く火炎帯に向かって拡散し，その 結果, 火炎温度が理論混合気よりむしろ希薄側で最高 となったものと考光らる。これに比較してプロパン 混合気では，プロパンと酸素の分子量があまり違わな いために, 圧力拡散による影響が顕著にでなかったと 考えられる。

しかし,この圧力拡散の影響については, 本バーナ で実験するだけでは結論を得るには不十分であり，同 じ接線吹出でも管径の異なるバーナや，同じ軸方向平 均速度でも回転強さの異なるバーナを用いて実験を行 うほか, 実際にガス分析を行って圧力拡散と濃度拡散 の影響を定量的に把握する必要があると思われる。

\section{5. まとめ}

メタンを燃料とした場合の管状火炎バーナの燃焼特 性を調べ，その結果，以下のことが明らかになった。

（1）混合気総流量 $20 \sim 140 \mathrm{Nm}^{3} / \mathrm{h}$ に対し,プロ パンの場合と同様に，均一で大きな層流火炎面面積を もつ管状火炎が形成される。ただし，プロパンでは燃 料過剰側で大きな火炎面面積が得られるのに対し, メ タンでは燃料希薄側で最大で約 $0.24 \mathrm{~m}^{2}$ の均一な層流 火炎面面積をもつ管状火炎が形成された。

（2）この管状火炎の希薄側の消炎限界は， $\Phi \cong$ 0.5 でプロパンと同様希薄可燃限界近くまで火炎が形 成可能であるが, 過濃側は総流量の増加に伴い火炎安 定範囲は狭まり, 最大流量約 $160 \mathrm{Nm}^{3} / \mathrm{h}\left(\alpha=18 \mathrm{~s}^{-1}\right)$

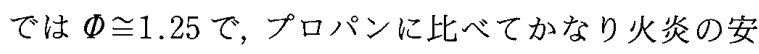
定範囲が狭い。

（3）半径方向温度分布は, プロパンと同様 M 形 で，自己冷却作用により吹出し部壁面は常温に保たれ， また, 燃焼ガスの軸方向温度分布もほとんど一定で均 一な燃焼がス領域が形成されることが確認できた。

（4）火炎直径は, 燃料希薄側の $\Phi=0.9$ 付近で最 大となり希薄, 過濃側でやや減少する。また, 火炎長 さも $\Phi=0.9$ 付近で最短となり，希薄，過濃側で大き く増加する，この炎炎直径，火炎長さのピーク位置は， 
プロパンの場合に比べより希薄側にずれている.

（5）熱電対で測定された火炎温度も，燃料希薄側 の $\Phi=0.9$ 付近で最高となり, それより希薄側, 過濃 側で減少するが，ふく射補正を施した值は，希薄側で ほぼ平衡計算値に一致し，一方，過濃側では当量比の 増加とともに急激に減少して平衡計算値を大きく下回 る.

（6）体積燃焼速度は， $\Phi=1.0$ 付近では理論值で ある混合気流量にほほ等しいが，吹消え限界付近の希 薄混合気や過濃混合気ではそれぞれ $50 \%$ ぐらい理論 值より小さくあるいは大きくなる。この原因として は, 燃焼速度が最大となる当量比 (1.05)に比べ, 火炎 直径や火炎長さ, 火炎温度がピークとなる当量比がか なり燃料希薄側に移動して 0.9 付近となることが挙げ られる。

（7）なお，このピーク位置が $\Phi=0.9$ 付近にずれ る原因としては，通常の濃度拡散における選択拡散の ほかに，メタンと酸素の分子量の違いに関係した圧力 拡散が考えられるが，回転強さや管径を変えた実験や ガス分析などで定量的に確かめる必要がある.

本実験を行うにあたりご協力いただいた広島大学大 学院院生 水口裕之, 工学部学生 中野雅司, 長友真
吾の各氏に謝意を表す。

\section{文献}

(1) Ishizuka, S., Proc. 20th Symp. (Int.) Combust., The Combustion Institute, Pittsburgh, (1984), 287-294.

(2) Takeno, T. and Ishizuka, S., Combust. Flame, 64(1986), 93-98.

(3) Ishizuka, S., Combust. Flame, 75(1989), 367-379.

(4) Ishizuka, S., Prog. Energy Combust. Sci., 19(1993), 187226.

（5）石塚悟・萩原良一・鈴木実・中村章・濱口㥎，機論，65639, B (1999), 3845-3852.

(6) Zabetakis, M. G., Bull. US Bureau Mines, 627 (1965).

（7）平野敏右, 燃焼学, (1980), 113, 海文堂, 東京.

(8) Gordon, A. and McBride, B. J., NASA SP-273(1971).

(9) Kaskan, W. E., Proc. 6th Symp. (Int.) Combust., Reinhold Publishing Co., New York, (1957), 134-143.

(10) Hirschfelder, J. O., Curtiss, C.F. and Bird, R. B., Molecular Theory of Gases and Liquids, (1954), 514610, John Wiley \& Sons, Inc., New York.

(11) Nishioka, M., Ishizuka, S. and Takeno, T., Combust. Flame, 73 (1988), 287-301.

(12) Yamaoka, I. and Tsuji, H., Proc. 20th Symp. (Int.) Combust., The Combustion Institute, Pittsburgh, (1984), 1883-1892.

(13) Kobayashi, H. and Kitano, M., Combust. Flame, 76 (1989), 285-295.

(14) Sakai, Y. and Ishizuka, S., Proc. 24th Symp. (Int.) Combust., The Combustion Institute, (1992), 153-159. 